\title{
The Selenium Status of Dairy Cattle in Estonia
}

The concentration of selenium in soils and crops varies widely in different parts of the world. The selenium status of many countries is unknown, but there is evidence that selenium deficient crops occur in every continent. Surveys in Finland (Oksanen \& Sandholm 1970), Norway (Mikkelsen \& Aas Hansen 1967), Denmark (Gissel-Nielsen 1975) and Sweden (Lindberg \& Bingefors 1970) were among the first to investigate selenium status and they showed that each of these countries was very deficient. As a result selenium was permitted to be included as a supplement in animal feeds, in Finland from 1969, in Denmark from 1975, and in Norway and Sweden from 1980.

The knowledge about the selenium status of Estonia is incomplete. In 1993 we analysed a few samples of blood and milk from Estonian cows and found that they were very low in selenium. Suoranta et al. (1993) also recorded very low selenium concentrations in feedstuffs, milk and tissues from one Estonian dairy farm, and recently Malbe et al. (1995) reported that the selenium status of the Estonian Agricultural University farm was also very low. In a recent study Kevvai (1997) measured the selenium content in 13 different Estonian soils and found a mean value of $172 \mathrm{ng} / \mathrm{g}$ (range: 10-443), which could be compared with the concentrations found in Swedish soils ( $\bar{x}$ : $390 \mathrm{ng} / \mathrm{g}$, range: 85-976; Lindberg \& Bingefors 1970), in soils from lowselenium regions in USA (range: $60-620 \mathrm{ng} / \mathrm{g}$;
Cary et al. 1967), and in the low-selenium Keshan disease areas in China ( $\overline{\mathrm{x}}: 122 \mathrm{ng} / \mathrm{g}$, range: 59-190; Sun et al. 1985).

This paper describes an investigation of the selenium status in Estonian cows, who had been given no or only insignificant selenium supplementation.

Eleven dairy herds from the central regions of the country were studied (Fig.1). The number of cows in the herd varied from 60 to 650 . The herds were selected by Estonian advisers and veterinarians as being representative for conventional Estonian dairy herds. Nothing was known in advance about the farms' feeding regimens, and information was obtained from interviews with the herdsmen at each farm.

Seven of the farms used a mineral feed containing no added selenium. In 4 herds minor amounts ( $<50$ g per cow) of a commercial mineral feed supplemented with $10 \mathrm{mg}$ selenium per $\mathrm{kg}$ as selenite were given, but not each day. (In a twelfth herd $>100 \mathrm{~g}$ of a selenium- supplemented mineral feed was given to each single cow each day. This herd was not included in the evaluation).

All the herds fed hay and silage, and oats, barley or wheat. Four herds also fed fodder beets, and 2 fed potatoes. All these feedstuffs were home-produced. In addition, all the herds which were not supplemented with selenium and 2 of those which were supplemented with selenium also fed sunflower or cotton meal as 


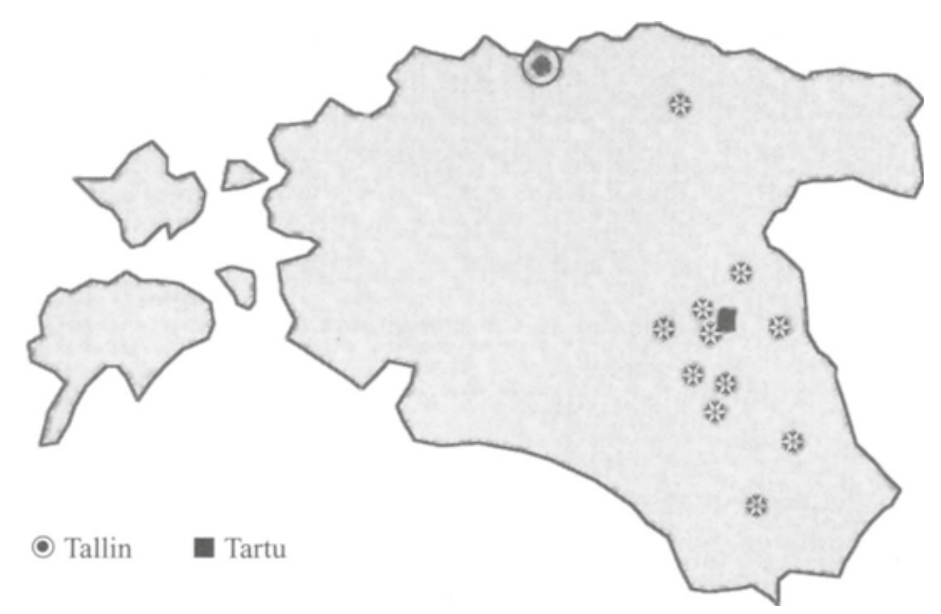

Figure 1. The geographic position of Estonian farms included in the study.

protein supplements, all of them imported from Russia. Six of these herds fed up to $1 \mathrm{~kg}$, two fed up to $2 \mathrm{~kg}$ and one fed up to $2.5 \mathrm{~kg}$ of these supplements. Their selenium concentrations were analysed by the method of Sari et al. (1975), and found to be between 0.13 and 0.30 $\mathrm{mg} / \mathrm{kg}$, with a mean of $0.23 \mathrm{mg} / \mathrm{kg}$ from $8 \mathrm{sam}$ ples.

Blood samples were taken from 5-10 lactating cows and 2-5 dry cows in each herd. They were analysed for the activity of glutathione peroxidase (Ery-GSH-Px) in the erythrocytes by the method of Paglia \& Valentine (1967). The EryGSH-Px activities of the lactating and dry cows were very similar and they have therefore been considered as a single group.

Milk samples were taken from the lactating cows and analysed for selenium by the method of Sari et al. (1975).

The results are presented in Table 1 . The mean activity of Ery-GSH-Px of the cows in the 7 herds which did not receive supplementary selenium ranged from 20-98 $\mu \mathrm{kat} / \mathrm{l}$; the corresponding figures for the 4 herds which did receive supplementary selenium were 43-127 $\mu \mathrm{kat} / \mathrm{l}$. When the correlation found at our labor- atory (Carlström et al. 1979) is used, these ranges are equivalent to whole blood selenium concentrations of 230-300 nmol/1 and 250-350 nmol/1, respectively. ${ }^{1}$

It is generally agreed that the whole blood selenium concentration should be at least 630 $\mathrm{nmol} / \mathrm{l}$; comparable to about $400 \mu \mathrm{katEry}-$ $\mathrm{GSH}-\mathrm{Px} / \mathrm{l}$ erythrocytes in our laboratory. The mean values in all the 11 herds were well below this level. In fact, no single cow in these herds reached an Ery-GSH-Px value of $400 \mu \mathrm{kat} / \mathrm{l}$; the lowest and highest individual values measured were 15 and $259 \mu \mathrm{kat} / 1$, respectively.

The mean equivalent whole blood selenium concentrations in all the 11 herds were similar to the levels observed by Pehrson et al. (1986) as typical of cattle which were predisposed to nutritional muscular degeneration. (The mean Ery-GSH-Px activity in the excluded herd, which regularly offered each cow $>100 \mathrm{~g}$ of a selenium-supplemented mineral feed, was 627

\footnotetext{
${ }^{1}$ In most earlier publications the selenium concentrations in blood and milk has been given as $\mu \mathrm{g} / \mathrm{l} ; 1$ $\mu \mathrm{g}=12.7 \mathrm{nmol}$.
} 
Table 1. The average annual milk production, herd size, number of sampled animals, erythrocyte GSH-Px activity and milk selenium concentration in cows from 11 herds from central Estonia.

\begin{tabular}{|c|c|c|c|c|c|c|c|c|c|}
\hline \multirow{2}{*}{ Farm } & \multirow{2}{*}{$\begin{array}{l}\text { Milk } \\
\text { yield, kg }\end{array}$} & \multirow{2}{*}{$\begin{array}{l}\text { Selenium } \\
\text { suppl. }\end{array}$} & \multirow[b]{2}{*}{$\mathrm{n}^{1}$} & \multicolumn{3}{|c|}{ GSH-Px, $\mu \mathrm{kat} / \mathrm{l}$} & \multicolumn{3}{|c|}{ Milk selenium, $\mathrm{nmol} / \mathrm{l}$} \\
\hline & & & & $\mathrm{n}^{2}$ & $\overline{\mathrm{x}}$ & SD & $\mathrm{n}^{2}$ & $\overline{\mathrm{x}}$ & SD \\
\hline 1 & 5,500 & no & 160 & 10 & 85.6 & 15.1 & 9 & 82 & 15 \\
\hline 2 & 5,600 & no & 450 & 15 & 97.7 & 39.3 & 10 & 90 & 9 \\
\hline 3 & 3,000 & no & 130 & 15 & 29.1 & 9.2 & 9 & 49 & 15 \\
\hline 4 & 2,900 & no & 64 & 12 & 37.6 & 13.3 & 7 & 47 & 8 \\
\hline 5 & 4,500 & no & 650 & 15 & 46.1 & 14.9 & 10 & 71 & 29 \\
\hline 6 & 3,100 & no & 60 & 15 & 19.9 & 4.9 & 11 & 57 & 9 \\
\hline 7 & 3,000 & no & 250 & 14 & 64.4 & 12.9 & 10 & 57 & 16 \\
\hline 8 & 4,000 & yes & 81 & 14 & 127.2 & 48.7 & 10 & 78 & 14 \\
\hline 9 & 3,500 & yes & 450 & 10 & 66.7 & 22.4 & 8 & 28 & 5 \\
\hline 10 & 2,900 & yes & 114 & 12 & 43.1 & 14.9 & 7 & 51 & 16 \\
\hline 11 & 2,700 & yes & 117 & 15 & 80.4 & 36.3 & 10 & 51 & 11 \\
\hline
\end{tabular}

$n^{1}=$ number of cows in herd, $n^{2}=$ number of cows sampled.

$\mu \mathrm{kat} / \mathrm{l}$, corresponding to a selenium concentration of about $880 \mathrm{nmol} / \mathrm{l})$.

The mean concentration of selenium in the milk of the cows in the unsupplemented herds was $60 \mathrm{nmol} / \mathrm{l}$. In Sweden, even before commercial feedstuffs were supplemented with selenium, the average concentration of selenium in Swedish cows' milk was slightly higher $(90 \mathrm{nmol} / \mathrm{l}$; Norrman 1984); moreover, the mean activity of Ery-GSH-Px of typical Swedish cows at that time (163 $\mu \mathrm{kat} / \mathrm{l} ;$ Pehrson, unpublished) was also slightly higher than the mean activity in the unsupplemented cows in the present investigation $(57 \mu \mathrm{kat} / \mathrm{l})$. This difference might have been due to higher levels of imported protein feedstuffs having been fed to Swedish cows at that time than are fed to Estonian cows today. Nevertheless, the selenium status of Estonian cows seems to be basically similar to the selenium status of cows in Sweden, Norway and Finland. This conclusion is supported by 2 recent reports from 2 other Estonian farms; Suoranta et al. (1993) recorded a milk selenium concentration of $100 \mathrm{nmol} / 1$ on one unsupplemented farm, and Malbe et al. (1995) recorded $40 \mathrm{nmol} / 1$ at another.
The only insignificantly higher Ery-GSH-Px activity in the selenium-supplemented herds than in the unsupplemented herds must have been a consequence of the low amounts of minerals fed. It is also remarkable that the mean milk selenium concentration was not higher in the supplemented group than in the unsupplemented; besides being a further indication that the level of selenium supplementation in fact was very low, one reason might be that inorganic selenium compounds have been found to be relatively ineffective for increasing the selenium concentration in milk (Ortman \& Pehrson 1997).

As a conclusion, the investigation gives further indications that Estonia is one of the highly selenium deficient countries of the world.

\section{Acknowledgements}

The investigation was supported by the Swedish Royal Academy of Agriculture and Forestry.

B. Pehrson ${ }^{I}, K$ Ling $^{2}$ and K. Ortman ${ }^{1}$

1 Department of Animal Environment and Health, Section of Field Research, Swedish University of Agricultural Sciences, Skara, Sweden.

2 Institute of Animal Husbandry, Estonian Agricultural University, Tartu, Estonia. 


\section{References}

Carlström G: On the determination of glutathione peroxidase. The distribution of the enzyme between blood plasma and erythrocytes in different animals. Proc. 21st World Veterinary Congress. Moscow, 1979, p. 55.

Carlström G, Jönsson G, Pehrson B: An evaluation of selenium status of cattle in Sweden by means of glutathione peroxidase. Swed. J. agric. Res. 1979, 9, 43-46.

Cary EE, Wiekzorek GA, Allaway WH: Reactions of selenite-selenium added to soils that produce low-selenium forage. Soil Sci. Soc. Amer. Proc. 1967, 31, 21-26.

Gissel-Nielsen G: Selenium concentration in Danish forage crops. Acta Agric. Scand. 1975, 25, 216-220.

Kevvai T: About the content of selenium in profiles of some field soils in Estonia. Scientific Reports. Estonian Agricultural University, Tartu 1997. p. 72-78.

Lindberg P, Bingefors $S$ : Selenium levels in forages and soil in different regions of Sweden. Acta. Agric. Scand. 1970, 20, 133-136.

Malbe M, Klaassen M, Fang W, Myllys W, Vikerpuur $M$, Nyholm K, Sankari S, Suoranta K, Sandholm $M$ : Comparisons of selenite and selenium yeast feed supplements on Se-incorporation, mastitis and leucocyte function in Se-deficient dairy cows. J. Vet. Med. A, 1995, 42, 111-121.

Mikkelsen T, Aas Hansen M: Undersøkelse over selen og muskeldegenerasjon hos lam i Rørosdistriktet.
(Studies on selenium and muscular degeneration in lambs in Røros, Norway). Nord. Vet.-Med. 1967, 19, 393-410. In Norwegian.

Norrman E: Mjölkens innehåll av selen. (The selenium content in cow's milk). Nord. Vet.-Med. 1984, 36, 296-304. In Swedish.

Oksanen HE, Sandholm M: The selenium content of Finnish forage crops. J. Sci. Agr. Soc. Fin. 1970, $42,250-253$.

Ortman $K$, Pehrson B: Selenite and selenium yeast as feed supplements for dairy cows. J. Vet. Med. A. 1997, 44, 373-380.

Paglia DE, Valentine $W N$ : Studies on the quantitative and qualitative characterization of erythrocyte glutathione peroxidase. J. Lab. Clin. Med. 1967, 70, 158-169.

Pehrson B, Hakkarainen J, Työppönen J: Nutritional muscular degeneration in young heifers. Nord. Vet.-Med. 1986, 38, 26-30.

Sari E, Siemmer D, Hageman L: Modified atomic absorbtion spectrophotometric determination of selenium in foodstuffs by hydride generation. Anal. Letters 1975, 8, 323-337

SAS Institute Inc: SAS/STAT Guide for personal computers. Version 6 Edition Cary, NC, 1987.

Sun S, Zhai F, Zhou L, Yang G: The bioavailability of soil selenium in Keshan disease and high selenium areas. Chinese J. End. Dis. 1985, 4, 21-28.

Suoranta K, Sinda E, Pihlak R: Selenium of the selenium yeast enters the cow's milk. Norw. J. Agric. Sci. 1993, suppl. 11, pp. 215-216.

(Received April 11, 1996; accepted November 1, 1997).

Reprints may be requested from: B. Pehrson, Department of Animal Environment and Health, Section of Field Research, Swedish University of Agricultural Sciences, P.O.Box 234, S-532 23 Skara, Sweden.

E-mail: Bo.Pehrson@hmh.slu.se, fax: +46 511-67134, tel: +46 511-67127. 